\title{
Empirical Research on the Impact of Real Estate on Economic Development
}

\author{
Shichang Shen \\ School of Mathematics and Statistics, Qinghai Nationalities University, Xining, China \\ Email: 13909785766@163.com
}

How to cite this paper: Shen, S.C. (2021) Empirical Research on the Impact of Real Estate on Economic Development. Journal of Mathematical Finance, 11, 246-254. https://doi.org/10.4236/jmf.2021.112014

Received: March 5, 2021

Accepted: May 14, 2021

Published: May 17, 2021

Copyright (c) 2021 by author(s) and Scientific Research Publishing Inc. This work is licensed under the Creative Commons Attribution International License (CC BY 4.0).

http://creativecommons.org/licenses/by/4.0/

\begin{abstract}
Real estate development investment has a significant impact on economic development. Based on data from 17 prefecture-level cities and prefectures in Hubei Province from 2002 to 2018, the relationship between real estate development investment and economic growth is analyzed with the help of panel data models. The study found that there is a long-term equilibrium relationship between the two, and there are regional differences in the impact of real estate development investment on economic growth in Hubei Province. Among them, Wuhan has the largest impact and Shennongjia forest area has the smallest impact. The impact of real estate development investment on economic growth depends on the level of regional economic development.
\end{abstract}

\section{Keywords}

Real Estate, Economic Growth, Panel Data Model

\section{Introduction}

The real estate industry has been on the rise for many years. In recent years, despite the slowdown in the development of the real estate industry across the country, various provinces and cities have introduced various new housing policies in order to attract talent. It can be seen that, whether it is the direct impact of the real estate industry on economic growth in the past few decades or the indirect impact of the real estate industry on economic growth in recent years, it shows that the real estate industry is an important long-term effective factor for economic growth. Therefore, many scholars [1] [2] [3] [4] [5] discussed the relationship between real estate development investment and economic growth, mainly using the following two methods: the first is to discuss the cause and effect of real estate development investment and economic growth based on Granger causality test [6] relationship; the second is to use time series data to 
establish a vector autoregressive (VAR) model [6] to study the interactive relationship between real estate development investment and economic growth. This paper uses panel data to establish a fixed-effect variable coefficient model [7] to conduct an empirical analysis of the relationship between real estate development investment and economic growth in 17 prefecture-level cities and prefectures in Hubei Province from 2002 to 2018.

\section{Empirical Analysis}

\subsection{Data Description}

This article selects the annual data of cities and states in Hubei Province from 2002 to 2018. The gross product of each city and state is taken as the explanatory variable and expressed by GDP. The investment scale of real estate development, infrastructure investment scale and technological transformation investment scale of each city and state are taken as the explanatory variable and expressed by REI, INF and TEC respectively. Before establishing the model, we perform a natural logarithmic transformation on each data, which can both eliminate heteroscedasticity and make the data series more stable. The data comes from $\mathrm{Hu}$ bei Statistical Yearbook.

\subsection{Unit Root Test}

To prevent false regression or false regression, we use LLC, IPS, ADF, PP-Fisher four test methods to analyze the stability of the data, as shown in Table 1.

Table 1. Unit root test of panel data.

\begin{tabular}{|c|c|c|c|c|}
\hline Variable & LLC test & IPS test & ADF test & PP-Fisher test \\
\hline LnGDP & $\begin{array}{c}-0.34424 \\
(0.3653)^{\star \star}\end{array}$ & $\begin{array}{c}5.07864 \\
(1.0000)^{\star *}\end{array}$ & $\begin{array}{c}8.37431 \\
(1.0000)^{\star *}\end{array}$ & $\begin{array}{c}6.93169 \\
(1.0000)^{\star *}\end{array}$ \\
\hline$\Delta \mathrm{LnGDP}$ & $\begin{array}{c}-25.3064 \\
(0.0000)^{\star *}\end{array}$ & $\begin{array}{c}-12.5603 \\
(0.0000)^{\star \star}\end{array}$ & $\begin{array}{c}125.554 \\
(0.0000)^{\star *}\end{array}$ & $\begin{array}{c}134.834 \\
(0.0000)^{\star *}\end{array}$ \\
\hline LnREI & $\begin{array}{c}-5.09708 \\
(0.0000)^{\star *}\end{array}$ & $\begin{array}{c}0.18295 \\
(0.5726)^{\star *}\end{array}$ & $\begin{array}{c}28.8456 \\
(0.6270)^{\star *}\end{array}$ & $\begin{array}{c}49.1685 \\
(0.0268)^{\star \star}\end{array}$ \\
\hline$\Delta \mathrm{LnREI}$ & $\begin{array}{c}-8.79931 \\
(0.0000)^{\star *}\end{array}$ & $\begin{array}{c}-7.50299 \\
(0.0000)^{\star *}\end{array}$ & $\begin{array}{c}114.362 \\
(0.0000)^{\star \star}\end{array}$ & $\begin{array}{c}130.928 \\
(0.0000)^{\star *}\end{array}$ \\
\hline LnINF & $\begin{array}{l}-2.96376- \\
(0.0015)^{\star *}\end{array}$ & $\begin{array}{c}2.69346 \\
(0.9965)^{\star *}\end{array}$ & $\begin{array}{c}19.6971 \\
(0.9761)^{\star *}\end{array}$ & $\begin{array}{c}13.7760 \\
(0.9992)^{\star *}\end{array}$ \\
\hline$\Delta \mathrm{LnINF}$ & $\begin{array}{c}-7.48415 \\
(0.0000)^{\star \star}\end{array}$ & $\begin{array}{l}-5.89356 \\
(0.0000)^{\star \star}\end{array}$ & $\begin{array}{c}96.1887 \\
(0.0000)^{\star *}\end{array}$ & $\begin{array}{c}98.6457 \\
(0.0000)^{\star *}\end{array}$ \\
\hline LnTEC & $\begin{array}{c}-1.46581 \\
(0.0713)^{\star *}\end{array}$ & $\begin{array}{c}1.69675 \\
(0.9551)^{\star *}\end{array}$ & $\begin{array}{c}17.0436 \\
(0.9932)^{\star *}\end{array}$ & $\begin{array}{c}18.4390 \\
(0.9863)^{\star *}\end{array}$ \\
\hline$\triangle \mathrm{LnTEC}$ & $\begin{array}{l}-8.53638 \\
(0.0000)^{\star *}\end{array}$ & $\begin{array}{c}-8.28401 \\
(0.0000)^{\star *}\end{array}$ & $\begin{array}{c}133.847 \\
(0.0000)^{\star *}\end{array}$ & $\begin{array}{c}125.490 \\
(0.0000)^{\star *}\end{array}$ \\
\hline
\end{tabular}

Note: $\Delta$ means first-order difference; ${ }^{\star *}$ means significance level of $5 \%$. 
As can be seen from the table above, the horizontal sequence of LnGDP, LnREI, LnINF and LnTEC cannot reject the null hypothesis that unit roots exist at a significant level of $5 \%$. However, the $\mathrm{P}$ values of the $\triangle \mathrm{LnGDP}, \triangle \mathrm{LnREI}$, $\triangle \mathrm{LnINF}$ and $\triangle \mathrm{LnTEC}$ sequences after the first-order difference are all 0 , that is, the null hypothesis is rejected, indicating that the first-order difference sequence of the sequence is stable.

\subsection{Panel Data Cointegration Test}

Because the sequence $\Delta \mathrm{LnGDP}, \Delta \mathrm{LnREI}, \Delta \mathrm{LnINF}$ and $\Delta \mathrm{LnTEC}$ are all I(1) sequences, the conditions of the cointegration test are satisfied. And the first-order difference sequences of the four variables are all stable, meeting the premise of the co-integration test. In order to ensure the accuracy, the author uses the Pedroni test, Kao test, and Combined Individual test to verify at the same time. The original hypothesis of these three tests is that there is no co-integration. The test results are shown in Table 2.

The results in Table 2 indicate that at the significance level of 5\%, the P statistics of Panel PP-Statistic, Panel ADF-Statistic, Group PP-Statistic, and Group ADF-Statistic of the Pedroni test are all 0, and most of the test results are rejected. The null hypothesis indicates the existence of cointegration. However, the other three statistics of the Pedroni test showed no co-integration. Therefore, in order to ensure accuracy, Kao test and Combined Individual test are needed to verify. As can be seen from the above table, the P statistic of the Kao test is less than $5 \%$, the null hypothesis of no co-integration is rejected, and the three hypotheses of the joint individual test are rejected. This shows that from 2000 to

Table 2. Co-integration test results of 17 prefecture-level cities and prefectures in Hubei Province.

\begin{tabular}{ccc}
\hline Statistical methods & Statistics & \\
\hline Pedroni Test & Panel v-Statistic & $-25.85242(1.0000)$ \\
& Panel rho-Statistic & $-1.318870(0.0936)$ \\
& Panel PP-Statistic & $-7.216089(0.0000)$ \\
& Panel ADF-Statistic & $-7.980418(0.0000)$ \\
& Group rho-Statistic & $2.161981(0.9847)$ \\
& Group PP-Statistic & $-4.032946(0.0000)$ \\
Kao Test & Group ADF-Statistic & $-5.359391(0.0000)$ \\
\hline Hypothesized No. of CE(s) & ADF & $-2.899656(0.0019)$ \\
\hline None & Fisher Stat. ${ }^{*}($ from trace test $)$ & Fisher Stat.* \\
At most 1 & $395.9(0.0000)$ & $256.5(0.0000)$ \\
At most 2 & $193.8(0.0000)$ & $128.9(0.0000)$ \\
At most 3 & $104.6(0.0000)$ & $69.87(0.0001)$ \\
\hline & $98.31(0.0000)$ & $98.31(0.0000)$
\end{tabular}


2016, there was a long-term stable and balanced relationship between investment in housing development, investment in infrastructure construction, and investment in technological transformation and GDP in Hubei Province.

\subsection{Panel Model Selection}

\subsubsection{Random Effect and Fixed Effect Test}

Likelihood ratio (LR) test is a test of the model's fixed effect. The null hypothesis of this test is that the fixed effect is redundant. From the results in Table 3, it can be clearly seen that the null hypothesis is rejected under the $5 \%$ confidence level That is, the fixed effects introduced are appropriate.

\subsubsection{F-Test of Panel Model}

Through calculation, we can get $F_{2}=21.77706, F_{2}=8.35356$. Given the significance level of $\alpha=5 \%$, we can know that $F_{2 \alpha}(60,208)=1.7, F_{\alpha}(45,208)$ $=1.39$. Because $F_{2}>1.7, H_{2}$ is rejected; and $F_{1}>1.39, H_{1}$ is rejected. Therefore, a fixed effect variable coefficient model should be established.

\subsubsection{Regression Estimation of Panel Model}

Based on the panel model's F-test and likelihood ratio (LR) test results, we establish a fixed-effect variable coefficient model for panel data from 17 cities and states in Hubei Province: LnGDP $=\alpha+\beta_{1}$ LnREI $+\beta_{2}$ LnINF $+\beta_{3}$ LnTEC . Eviews7.2 was used to estimate the model, and the results are as follows:

Table 4 and Table 5 show the results of applying fixed-effect variable coefficient models to the data of 16 prefecture-level cities in Hubei Province, as well as the results of goodness of fit, statistics, and statistics of regression equations.

As can be seen from the table, the estimated value of the explanatory variable at a significant level of $1 \%$ is valid, the goodness of fit $\mathrm{R}^{2}$ is above $99 \%$, and the $\mathrm{P}$ value of the F statistic is 0 . The value of D.W. is near 2 , which indicates that cross-section SUR is used to weight the explanatory variables to effectively reduce the effect of cross-section data on heteroscedasticity and correlation over the same period.

According to Table 6, from 2002 to 2018, for every 1\% increase in real estate development investment in Wuhan, GDP can increase by $0.76 \%$. The coefficient of real estate development investment in Wuhan is greater than the coefficient of infrastructure investment and technological transformation investment, indicating that production in Wuhan The total value relies heavily on real estate development investment. At the same time, the real estate development investment in Jingmen, Yichang, Xiantao, Jingzhou, Xiangyang, Enshi and Xiaogan has a positive effect on GDP. Then the investment coefficient of real estate development in these areas gradually decreases, and infrastructure investment tends to

Table 3. Likelihood ratio (LR) test results of panel data.

\begin{tabular}{cccc}
\hline Effects Test & Statistic & d.f. & Prob. \\
\hline Cross-section F & 167.739471 & $(15,208)$ & 0.0000 \\
\hline
\end{tabular}


Table 4. Regression estimation results of the fixed effect variable coefficient model.

\begin{tabular}{|c|c|c|c|c|}
\hline Variable & Coefficient & Std. Error & t-Statistic & Prob. \\
\hline $\mathrm{C}$ & 3.893797 & 0.036497 & 106.6871 & 0.0000 \\
\hline _WUHAN--LNREI_WUHAN & 0.767510 & 0.029072 & 26.40022 & 0.0000 \\
\hline _HUANGSHI--LNREI_HUANGSHI & -0.074545 & 0.028181 & -2.645229 & 0.0088 \\
\hline _SHIYAN--LNREI_SHIYAN & -0.123605 & 0.011623 & -10.63420 & 0.0000 \\
\hline _YICHANG--LNREI_YICHANG & 0.238224 & 0.015091 & 15.78616 & 0.0000 \\
\hline _XIANGYANG--LNREI_XIANGYANG & 0.061494 & 0.016581 & 3.708735 & 0.0003 \\
\hline _EZHOU--LNREI_EZHOU & -0.487179 & 0.068315 & -7.131344 & 0.0000 \\
\hline _JINGMEN--LNREI_JINGMEN & 0.637393 & 0.034066 & 18.71029 & 0.0000 \\
\hline _XIAOGAN--LNREI_XIAOGAN & 0.014907 & 0.015527 & 0.960084 & 0.3381 \\
\hline _JINGZHOU--LNREI_JINGZHOU & 0.099174 & 0.008775 & 11.30233 & 0.0000 \\
\hline _HUANGGANG--LNREI_HUANGGANG & -0.238633 & 0.049267 & -4.843672 & 0.0000 \\
\hline _XIANNING--LNREI_XIANNING & -0.009465 & 0.003580 & -2.643740 & 0.0088 \\
\hline _SUIZHOU--LNREI_SUIZHOU & -0.060376 & 0.009499 & -6.356215 & 0.0000 \\
\hline _ENSHI--LNREI_ENSHI & 0.014998 & 0.011027 & 1.360052 & 0.1753 \\
\hline _XIANTAO--LNREI_XIANTAO & 0.208718 & 0.011208 & 18.62234 & 0.0000 \\
\hline _QIANJIANG--LNREI_QIANJIANG & -0.104010 & 0.018586 & -5.596080 & 0.0000 \\
\hline _TIANMEN--LNREI_TIANMEN & -0.036792 & 0.019904 & -1.848501 & 0.0659 \\
\hline _WUHAN--LNINF_WUHAN & -0.056024 & 0.026100 & -2.146518 & 0.0330 \\
\hline _HUANGSHI--LNINF_HUANGSHI & 0.434497 & 0.029229 & 14.86517 & 0.0000 \\
\hline _SHIYAN--LNINF_SHIYAN & 0.533329 & 0.011686 & 45.63651 & 0.0000 \\
\hline _YICHANG--LNINF_YICHANG & 0.391790 & 0.017531 & 22.34847 & 0.0000 \\
\hline _XIANGYANG--LNINF_XIANGYANG & 0.375156 & 0.013325 & 28.15448 & 0.0000 \\
\hline _EZHOU--LNINF_EZHOU & 0.728457 & 0.064925 & 11.21992 & 0.0000 \\
\hline _JINGMEN--LNINF_JINGMEN & 0.072777 & 0.045336 & 1.605264 & 0.1100 \\
\hline _XIAOGAN--LNINF_XIAOGAN & 0.303147 & 0.012228 & 24.79151 & 0.0000 \\
\hline _JINGZHOU--LNINF_JINGZHOU & 0.339363 & 0.010867 & 31.22808 & 0.0000 \\
\hline _HUANGGANG--LNINF_HUANGGANG & 0.383484 & 0.050024 & 7.666012 & 0.0000 \\
\hline _XIANNING--LNINF_XIANNING & 0.455809 & 0.008218 & 55.46456 & 0.0000 \\
\hline _SUIZHOU--LNINF_SUIZHOU & 0.360856 & 0.013163 & 27.41409 & 0.0000 \\
\hline _ENSHI--LNINF_ENSHI & 0.550089 & 0.017115 & 32.14140 & 0.0000 \\
\hline _XIANTAO--LNINF_XIANTAO & 0.185374 & 0.010219 & 18.13984 & 0.0000 \\
\hline _QIANJIANG--LNINF_QIANJIANG & 0.451030 & 0.022516 & 20.03193 & 0.0000 \\
\hline _TIANMEN--LNINF_TIANMEN & 0.393772 & 0.033777 & 11.65792 & 0.0000 \\
\hline _WUHAN--LNTEC_WUHAN & -0.063750 & 0.005468 & -11.65869 & 0.0000 \\
\hline _HUANGSHI--LNTEC_HUANGSHI & 0.094647 & 0.011265 & 8.401604 & 0.0000 \\
\hline _SHIYAN--LNTEC_SHIYAN & -0.017637 & 0.009164 & -1.924659 & 0.0556 \\
\hline _YICHANG--LNTEC_YICHANG & 0.148625 & 0.013657 & 10.88293 & 0.0000 \\
\hline _XIANGYANG--LNTEC_XIANGYANG & 0.078553 & 0.012916 & 6.081914 & 0.0000 \\
\hline _EZHOU--LNTEC_EZHOU & -0.017275 & 0.046119 & -0.374571 & 0.7084 \\
\hline
\end{tabular}




\section{Continued}

\begin{tabular}{|c|c|c|c|c|}
\hline _JINGMEN--LNTEC_JINGMEN & -0.333959 & 0.036742 & -9.089352 & 0.0000 \\
\hline _XIAOGAN--LNTEC_XIAOGAN & 0.122958 & 0.007169 & 17.15131 & 0.0000 \\
\hline _JINGZHOU--LNTEC_JINGZHOU & 0.002828 & 0.010443 & 0.270832 & 0.7868 \\
\hline _HUANGGANG--LNTEC_HUANGGANG & 0.375891 & 0.038444 & 9.777748 & 0.0000 \\
\hline _XIANNING--LNTEC_XIANNING & 0.083043 & 0.005608 & 14.80787 & 0.0000 \\
\hline _SUIZHOU--LNTEC_SUIZHOU & 0.112562 & 0.008340 & 13.49713 & 0.0000 \\
\hline _ENSHI--LNTEC_ENSHI & -0.005566 & 0.010921 & -0.509620 & 0.6109 \\
\hline _XIANTAO--LNTEC_XIANTAO & 0.107345 & 0.005973 & 17.97113 & 0.0000 \\
\hline _QIANJIANG--LNTEC_QIANJIANG & 0.269593 & 0.014596 & 18.47091 & 0.0000 \\
\hline _TIANMEN--LNTEC_TIANMEN & -0.051777 & 0.022498 & -2.301400 & 0.0224 \\
\hline \multicolumn{5}{|l|}{ Fixed Effects (Cross) } \\
\hline _WUHAN--C & 0.228206 & & & \\
\hline _HUANGSHI--C & 0.113651 & & & \\
\hline _SHIYAN--C & 0.256524 & & & \\
\hline _YICHANG--C & -0.883834 & & & \\
\hline _XIANGYANG--C & 0.506471 & & & \\
\hline _EZHOU--C & -0.474434 & & & \\
\hline _JINGMEN--C & 1.627321 & & & \\
\hline _XIAOGAN--C & 0.427549 & & & \\
\hline _JINGZHOU--C & 0.496782 & & & \\
\hline _HUANGGANG--C & -0.214690 & & & \\
\hline _XIANNING--C & -0.468961 & & & \\
\hline _SUIZHOU--C & 0.046942 & & & \\
\hline _ENSHI--C & -0.879919 & & & \\
\hline _XIANTAO--C & 0.273954 & & & \\
\hline _QIANJIANG--C & -1.094671 & & & \\
\hline _TIANMEN--C & 0.039108 & & & \\
\hline
\end{tabular}

Effects Specification

Cross-section fixed (dummy variables)

Weighted Statistics

$\begin{array}{lccc}\text { R-squared } & 0.999992 & \text { Mean dependent var } & -394.5155 \\ \text { Adjusted R-squared } & 0.999989 & \text { S.D. dependent var } & 2532.235 \\ \text { S.E. of regression } & 1.027830 & \text { Sum squared resid } & 219.7385 \\ \text { F-statistic } & 398771.8 & \text { Durbin-Watson stat } & 2.131481 \\ \text { Prob (F-statistic) } & 0.000000 & & \\ & \text { Unweighted Statistics } & \\ \text { R-squared } & 0.986690 & \text { Mean dependent var } & 6.225209 \\ \text { Sum squared resid } & 3.702085 & \text { Durbin-Watson stat } & 1.349482\end{array}$


Table 5. Regression estimation results of the fixed effect variable coefficient model.

\begin{tabular}{ccccc}
\hline Area & Fixed effect & $\beta_{1}$ & $\beta_{2}$ & $\beta_{3}$ \\
\hline Wuhan & 0.228206 & 0.767510 & -0.056024 & -0.063750 \\
Huangshi & 0.113651 & -0.074545 & 0.434497 & 0.094647 \\
Shiyan & 0.256524 & -0.123605 & 0.533329 & -0.017637 \\
Yichang & -0.883834 & 0.238224 & 0.391790 & 0.148625 \\
Xiangyang & 0.506471 & 0.061494 & 0.375156 & 0.078553 \\
Ezhou & -0.474434 & -0.487179 & 0.728457 & -0.017275 \\
Jingmen & 1.627321 & 0.637393 & 0.072777 & -0.333959 \\
Xiaogan & 0.427549 & 0.014907 & 0.303147 & 0.122958 \\
Jingzhou & 0.496782 & 0.099174 & 0.339363 & 0.002828 \\
Huanggang & -0.214690 & -0.238633 & 0.383484 & 0.375891 \\
Xianning & -0.468961 & -0.009465 & 0.455809 & 0.083043 \\
Suizhou & 0.046942 & -0.060376 & 0.360856 & 0.112562 \\
Enshi & -0.879919 & 0.014998 & 0.550089 & -0.005566 \\
Xiantao & 0.273954 & 0.208718 & 0.185374 & 0.107345 \\
Qianjiang & -1.094671 & -0.104010 & 0.451030 & 0.269593 \\
Tianmen & 0.039108 & -0.036792 & 0.393772 & -0.051777 \\
\hline
\end{tabular}

Table 6. Regional differences in the impact of various investments on GDP.

\begin{tabular}{ccccccc}
\hline Area & $\begin{array}{c}\text { Impact of REI } \\
\text { on GDP }\end{array}$ & Ranking & $\begin{array}{c}\text { Impact of INF } \\
\text { on GDP }\end{array}$ & 排名 & $\begin{array}{c}\text { Impact of TEC } \\
\text { on GDP }\end{array}$ & Ranking \\
\hline Wuhan & 0.76751 & 1 & -0.056024 & 16 & -0.06375 & 15 \\
Jingmen & 0.637393 & 2 & 0.072777 & 15 & -0.333959 & 16 \\
Yichang & 0.238224 & 3 & 0.39179 & 8 & 0.148625 & 3 \\
Xiantao & 0.208718 & 4 & 0.185374 & 14 & 0.107345 & 6 \\
Jingzhou & 0.099174 & 5 & 0.339363 & 12 & 0.002828 & 10 \\
Xiangyang & 0.061494 & 6 & 0.375156 & 10 & 0.078553 & 9 \\
Enshi & 0.014998 & 7 & 0.550089 & 2 & -0.005566 & 11 \\
Xiaogan & 0.014907 & 8 & 0.303147 & 13 & 0.122958 & 4 \\
Xianning & -0.009465 & 9 & 0.455809 & 4 & 0.083043 & 8 \\
Tianmen & -0.036792 & 10 & 0.393772 & 7 & -0.051777 & 14 \\
Suizhou & -0.060376 & 11 & 0.360856 & 11 & 0.112562 & 5 \\
Huangshi & -0.074545 & 12 & 0.434497 & 6 & 0.094647 & 7 \\
Qianjiang & -0.10401 & 13 & 0.45103 & 5 & 0.269593 & 2 \\
Shiyan & -0.123605 & 14 & 0.533329 & 3 & -0.017637 & 13 \\
Huanggang & -0.238633 & 15 & 0.383484 & 9 & 0.375891 & 1 \\
Ezhou & -0.487179 & 16 & 0.728457 & 1 & -0.017275 & 12 \\
\hline
\end{tabular}


increase. Infrastructure investment in these regions has a greater impact on GDP. However, the real estate development investment in Xianning, Tianmen, Suizhou, Huangshi, Qianjiang, Shiyan, Huanggang and Ezhou has a negative effect on GDP, while the coefficient of infrastructure investment has gradually increased. Comparing the impact coefficients of real estate development investment, infrastructure investment and technological transformation investment on GDP, it is not difficult to find that for most cities, the impact of infrastructure investment on GDP is more significant.

\section{Conclusion}

This paper studies the relationship between real estate development investment and economic growth in 17 prefecture-level cities and prefectures in Hubei Province using stationary test, cointegration test and panel data regression estimation. The study found that there is a long-term equilibrium relationship between real estate development investment and economic growth in Hubei province. The influence of real estate development investment on GDP in Hubei Province has a large difference. For provincial capital cities with rapid economic development, real estate development investment has promoted GDP growth. For other prefecture-level cities with slower economic development, real estate development investment has a negative correlation with GDP. The impact of real estate development investment in Shennongjia forest area on GDP is zero, and many places in this area have been included in the national ecological protection area forbidden development. In view of the above, the relevant policy recommendations are as follows: 1) Implement regional real estate control policies. Due to the regional differences in the impact of real estate development investment on GDP, a one-size-fits-all policy should be avoided to assist in the implementation of regional real estate control policies. Specifically, in areas with high levels of economic development, the scale and growth rate of real estate investment should be controlled reasonably. For regions with low economic levels, the scale of real estate investment should be controlled, the development of the real estate industry should be stabilized, the growth rate of non-real estate investment should be accelerated, and the crowding out effect of the real estate industry on non-real estate industries should be avoided as much as possible, and should be reasonable and moderate to maintain the growth of investment in real estate development, and promote the steady and healthy coordinated development of the real estate industry. 2) Innovate regulatory measures and adapt to local conditions. Shiyan, Enshi and Shennongjia forest areas have more natural scenery. In order to avoid damage to the natural environment as much as possible, investment in real estate should be reduced, focus on the development of tourism to promote economic growth, do a good job in the construction of transportation facilities, pay attention to the construction of landscaping, environmental protection, technical services and other engineering facilities, so as to increase the amount of investment in infrastructure and technological transfor- 
mation. This can vigorously develop tourism to promote economic growth and protect the natural environment to a certain extent.

\section{Conflicts of Interest}

The author declares no conflicts of interest regarding the publication of this paper.

\section{References}

[1] Huang, Z.H.H. (2008) Real Estate Investment Economy and Economic Growth: Panel Data Analysis at the National and Regional Levels. Finance and Economics, No. 8, 56-61.

[2] Xie, N.F. (2017) Study on the Relationship between Real Estate Purchase, Real Estate Investment, Non-Real Estate Investment and Economic Growth. Journal of Kunming University of Science and Technology (Natural Science), No. 4, 117-126.

[3] Lai, Y.F. (2014) Correlation Model of Interest Rate Fluctuation, Real Estate Investment and Real Estate Price. Journal of Wuhan University (Engineering), No. 1, 96-99.

[4] Xiang, W.M. (2017) Real Estate Investment and Economic Growth: A Co-Integration Analysis Based on Chongqing. Journal of Chongqing University of Technology (Social Science), No. 8, 21-27.

[5] Chen, S.H.Y. (2012) Analysis of the Relationship between Urbanization, Real Estate Investment and Economic Growth. Economic System Reform, No. 2, 30-35.

[6] Yi, D.H. (2008) Data Analysis and Eviews Application. Renmin University of China Press, Beijing.

[7] Bai, Z.H.L. (2008) Econometric Analysis of Panel Data. Nankai University Press, Tianjin. 